\title{
Insulin-like growth factor-binding protein-4 inhibits growth of the thymus in transgenic mice
}

\author{
R Zhou 1, 2, H Flaswinkel', M R Schneider ${ }^{1}$, H Lahm ${ }^{3}$, A Hoeflich ${ }^{1}$, R Wanke ${ }^{4}$ and \\ E Wolf ${ }^{1}$ \\ ${ }^{1}$ Institute of Molecular Animal Breeding and Biotechnology, Gene Center of the University of Munich, 81377 Munich, Germany \\ ${ }^{2}$ College of Animal Science and Veterinary Medicine, Huazhong Agricultural University, 430070 Wuhan, China \\ ${ }^{3}$ Immunology-Molecular Biology Laboratory, Thoraxklinik Heidelberg gGmbH, 69126 Heidelberg, Germany \\ ${ }^{4}$ Institute of Veterinary Pathology, University of Munich, 80539 Munich, Germany
}

(Requests for offprints should be addressed to E Wolf; Email: ewolf@Imb.uni-muenchen.de)

\begin{abstract}
Numerous in vitro studies have demonstrated that IGF-binding protein (IGFBP)-4 is a consistent inhibitor of IGF actions. In order to investigate the functions of IGFBP-4 in vivo, transgenic mice were generated by microinjection of a transgene, in which the murine lgfbp 4 cDNA is driven by the $\mathrm{H}-2 \mathrm{~K}^{\mathrm{b}}$ promoter, and followed by a splicing cassette and polyadenylation signal of the human $\beta$-globin gene. Transgene mRNA was expressed ubiquitously, and elevated IGFBP-4 protein was detected in the spleen, thymus, kidney and lung of transgenic mice. The activities of serum IGFBPs were not changed in transgenic mice. Immunohistochemical studies revealed transgene expression predominantly in the thymic medulla and red pulp of the spleen. Body weight and the weights of the spleen, kidney and lung of transgenic mice were not different from controls. In contrast, the thymus of transgenic mice showed a significantly reduced weight and cortex volume. In transgenic thymus and spleen, cell proliferation was inhibited and apoptosis was stimulated. Transgenic mice showed normal T- and B-cell development and normal basal plasma immunoglobulin levels. In conclusion, overexpression of IGFBP-4 inhibits growth of the thymus. IGFBP-4 excess inhibits cell proliferation and stimulates apoptosis in lymphoid tissues, but does not affect lymphocyte development. These findings suggest that IGFBP-4 is a potential growth inhibitor of lymphoid tissues.
\end{abstract}

Journal of Molecular Endocrinology (2004) 32, 349-364

\section{Introduction}

Insulin-like growth factors-I and -II (IGFs-I and -II) are two important growth-promoting factors which regulate cellular survival, proliferation and differentiation (Stewart \& Rotwein 1996). Most of these actions are mediated by the type-I IGF receptor (IGF-IR) and are regulated by the IGF-binding proteins (IGFBPs), which represent a family of six secreted proteins with a common domain organization (Hwa et al. 1999). Despite their structural similarity, each IGFBP has unique properties and exhibits specific functions. IGFBPs inhibit and/or potentiate IGF actions, and some of them have effects independent of IGF binding (Firth \& Baxter 2002, Mohan \& Baylink 2002).
Among the six IGFBPs, IGFBP-4 is the smallest one and exists in both non-glycosylated $(24 \mathrm{kDa})$ and N-glycosylated (28 kDa) forms in all biological fluids. IGFBP-4 is unique among the six IGFBPs in having two extra cysteine residues in the variable central domain, which are linked by a disulfide linkage. IGFBP-4 is expressed by a wide range of cell types and tissues, and its expression is regulated by different mechanisms in a cell-type-specific manner (for review see Zhou et al. 2003).

IGFBP-4 was first described on the basis of its ability to potently inhibit bone cell growth (Mohan et al. 1989) and follicle-stimulating hormone (FSH)-stimulated steroid production of ovarian granulosa cells (Ui et al. 1989). It binds IGF-I and IGF-II with similar affinities and inhibits their 
actions under most physiological and pathological conditions. IGFBP-4 inhibits IGF-induced cell proliferation and differentiation in many cell types (for review see Zhou et al. 2003). Local administration of recombinant IGFBP-4 inhibited IGF-Iinduced increases of bone formation in mice (Miyakoshi et al. 1999). In contrast, systemic administration of IGFBP-4 stimulated bone formation, probably due to increasing IGF bioavailability via an IGFBP-4 protease-dependent mechanism (Miyakoshi et al. 2001). Transgenic mice overexpressing IGFBP-4 selectively in smooth muscle cells exhibited smooth muscle hypoplasia (Wang et al. 1998), which was in direct contrast to the smooth muscle hypertrophy induced by IGF-I overexpression (Wang et al. 1997). Moreover, a protease-resistant IGFBP-4 had more potency (Zhang et al. 2002), and IGF-I/IGFBP-4 double transgenic mice showed a reduction in wet weight of selected smooth muscle tissues (Wang et al. 1998), suggesting that these inhibitory effects of IGFBP-4 are IGF-I dependent.

In addition, IGF-independent actions of IGFBP-4 have also been suggested (for review see Zhou et al. 2003). However, unlike IGFBPs-3 and -5 , a specific receptor for IGFBP-4 has not been identified yet.

In order to investigate the function of IGFBP-4 in vivo, we generated transgenic mice overexpressing murine IGFBP-4 under the control of the murine $\mathrm{H}-2 \mathrm{~K}^{\mathrm{b}}$ promoter. The latter was isolated from a class I gene of the major histocompatibility complex and shown to facilitate ubiquitous expression of transgenes with high levels in lymphoid organs (Morello et al. 1986). As the IGFBP-4 transgene was highly expressed in the spleen and thymus, we focused on the characterization of effects on growth and development of lymphoid organs.

\section{Materials and methods}

\section{Construction and transfection of pH-2K ${ }^{\mathrm{b}}$-mIGFBP-4}

The mouse Igfbp4 complementary DNA (kindly donated by Dr Drop, University of Rotterdam, The Netherlands) was released from pGEM4ZmIGFBP-4, blunt ended and cloned into the blunted SalI restriction site of the mammalian expression vector pUG-H2 XXS (Plitz et al. 1999).

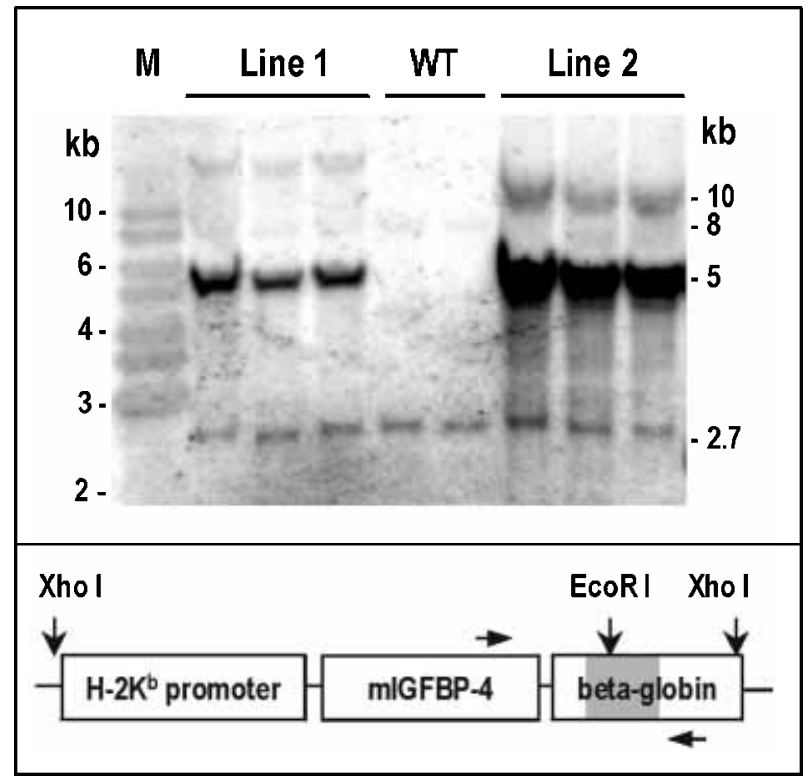

Figure 1 Upper panel, identification of IGFBP-4 transgenic lines by Southern blot analysis. Ten micrograms of genomic DNA of two wild-type (WT) mice and three transgenic mice from the two transgenic lines were digested with EcoRI and analyzed by Southern blot hybridization, using an $\alpha-\left[{ }^{32} \mathrm{P}\right] \mathrm{dCTP}$-labeled IGFBP-4 CDNA probe. A kilobase DNA ladder (M) was loaded as the molecular weight standard. Lower panel, schematic representation of the $\mathrm{H}-2 \mathrm{~K}^{\mathrm{b}}-\mathrm{mlGFBP}-4$ construct. The Xhol microinjection fragment $(5 \mathrm{~kb})$ contains the $\mathrm{H}-2 \mathrm{~K}^{\mathrm{b}}$ promoter $(2.1 \mathrm{~kb})$, the murine IGFBP-4 cDNA (mIGFBP-4, $1176 \mathrm{bp}$ ), and a $1.7 \mathrm{~kb}$ human $\beta$-globin splice cassette (beta-globin) including the last $20 \mathrm{bp}$ of exon 2, all of intron 2 (850 bp; shaded box) and exon 3 (228 bp) and the polyadenylation signal sequence (593 bp). Transgene-specific PCR primers are indicated by arrows.

The orientation of the insert in the sense direction was confirmed by restriction enzyme digest. The construct $\mathrm{pH}-2 \mathrm{~K}^{\mathrm{b}}$-mIGFBP-4 (Fig. 1) was tested by transient transfection of murine NIH-3T3 cells (ATCG, Manassas, VA, USA; 60\% confluent in a six-well plate) with $4 \mu \mathrm{g} \mathrm{pH}-2 \mathrm{~K}^{\mathrm{b}}-\mathrm{mIGFBP}-4$ or the mock vector pUC-H2 XXS using SuperFect transfection reagent (Qiagen, Hilden, Germany) according to the manufacturer's instructions. Transfected monolayers were washed once with PBS (pH 7.4), kept in the culture medium (Dulbecco's modified Eagle's medium (DMEM) with $10 \%$ fetal calf serum; Gibco) for $48 \mathrm{~h}$, and then washed twice with PBS and incubated with $2 \mathrm{ml}$ serum-free medium for another $48 \mathrm{~h}$. The serum-free conditioned media (SFGM) 
were analyzed by Western ligand and Western immunoblot.

\section{Generation of transgenic mice}

All mice were purchased from Elevage Janvier (Le Genest-Saint-Isle, France) and Charles River Laboratories (Sulzfeld, Germany), and were maintained and bred under specific pathogen-free conditions according to the guidelines of the Federation of European Laboratory Animal Science Associations (FELASA). Transgenic mice were generated by microinjection of the $5 \mathrm{~kb}$ XhoI fragment released from the expression vector $\mathrm{pH}-2 \mathrm{~K}^{\mathrm{b}}$-mIGFBP-4 into pronuclei of $\mathrm{F} 2$ zygotes from B6D2F1 (C57BL/6 $\times$ DBA/2) parents (Charles River Laboratories). The microinjected zygotes were implanted into the oviducts of pseudopregnant Naval Medical Research Institute (NMRI) mice (Charles River Laboratories) and carried to term. Founder transgenic mice were backcrossed with wild-type C57BL/6 mice (Elevage Janvier) for establishment and propagation of lines. Transgenic mice were identified by PCR (Taq DNA polymerase; Qiagen, Hilden, Germany) using DNA from tail clips. The tail tips of 3-week-old mice were lysed overnight in Kawasaki buffer (20 mM Tris-HCl (pH 7.5), $1.5 \mathrm{mM} \mathrm{MgCl}_{2}, 25 \mathrm{mM} \mathrm{KCl}, 0.5 \%$ (v/v) Tween 20) containing $1.2 \mathrm{mg} / \mathrm{ml}$ proteinase $\mathrm{K}$ at $56^{\circ} \mathrm{C}$. The samples were then heated at $95{ }^{\circ} \mathrm{C}$ for $15 \mathrm{~min}$ to inactivate the proteinase $\mathrm{K}$, and centrifuged at $15300 \mathrm{~g}$ and $4{ }^{\circ} \mathrm{C}$ for $5 \mathrm{~min} ; 2 \mu \mathrm{l}$ of the supernatant were used for PCR analysis. The integrity of the genomic DNA was confirmed by amplifying a sequence of the housekeeping gene $\beta$-actin as described previously (Schneider et al. 2001). The integration of the construct was determined by PCR using sense primer mBP4\#14 within the Igfbp4 cDNA (5'-TAA GCG TGA GCG TTC TCG TG-3') and antisense primer $\beta$-globin\#1 within the downstream exon of the $\beta$-globin splice cassette (5'-GGC AGG CTG CAC TGG TGG-3'). Both PGR amplifications were performed as follows: $94{ }^{\circ} \mathrm{C}$ for $4 \mathrm{~min}$, followed by 35 cycles of $94{ }^{\circ} \mathrm{C}$ for $1 \mathrm{~min}, 60^{\circ} \mathrm{C}$ for $1 \mathrm{~min}$ and $72{ }^{\circ} \mathrm{C}$ for $2 \mathrm{~min}$. After a final $10 \mathrm{~min}$ extension at $72{ }^{\circ} \mathrm{C}$ the amplified products were separated in $1 \cdot 2 \%$ agarose gels and visualized by ethidium bromide staining under u.v. light. The transgene integration pattern was analyzed by Southern blot as described previously (Hoeflich et al. 1999) using an $\left[\alpha-{ }^{32} \mathrm{P}\right] \mathrm{dCTP}$-labeled mouse IGFBP-4 cDNA probe. Genomic DNA was isolated from tail biopsies using the Wizard genomic DNA purification kit (Promega) and hydrolysed with EcoRI. Transgene expression was determined by reverse transcription (RT)-PCR, Western ligand and Western immunoblot analyses.

\section{RT-PCR}

The human $\beta$-globin splicing cassette in the transgene construct allows the differentiation of transgene-specific transcripts from the endogenous IGFBP-4 mRNA by RT-PCR. Total RNA was isolated from the cell cultures and different mouse tissues using the TriPure isolation reagent (Roche) according to the manufacturer's instructions. RT was performed as described previously (Schneider et al. 2001). PCR amplification was carried out using the transgene-specific primers $\mathrm{mBP} 4 \# 14$ and $\beta$-globin\#1 and the $\beta$-actin primers as described above. Control PCR reactions omitting RT and cDNA were also carried out.

\section{Western ligand blot}

Tissue samples $(20 \mathrm{mg})$ were homogenized in $0.5 \mathrm{ml}$ protein extraction buffer $(20 \mathrm{mM}$ Tris$\mathrm{HCl}(\mathrm{pH} 7 \cdot 5)$ and $2 \%(\mathrm{v} / \mathrm{v})$ Triton $\mathrm{X}-100$ in Laemmli buffer) using a cell homogenizer (ART, Muehlheim, Germany); $50 \mu \mathrm{g}$ of protein from the tissue extracts, $1 \mu \mathrm{l}$ serum or $16 \mu \mathrm{l}$ SFGM were diluted in Laemmli buffer, boiled for 5 min, separated on 5\% stacking/15\% separating SDS-polyacrylamide gels, and electroblotted to polyvinylidene difluoride (PVDF) membranes (Millipore, Bedford, MA, USA). Western ligand blotting was carried out as described previously using an ${ }^{125}$ I-labeled recombinant human IGF-II tracer (Schneider et al. 2001).

\section{Western blot}

Blots were prepared as above, washed once in TBS-T (20 mM Tris-HCl (pH 7·6), 137 mM NaCl, $0 \cdot 1 \%$ Tween-20) at room temperature for $10 \mathrm{~min}$ and blocked at $4{ }^{\circ} \mathrm{C}$ overnight with blocking solution (TBS-T containing 3\% (w/v) fat-free 
milk powder). Thereafter the blots were incubated at room temperature for $60 \mathrm{~min}$ with the rabbit anti-IGFBP-4 polyclonal antiserum (Upstate Biotechnology, Lake Placid, NY, USA) diluted 1:1000 in blocking solution, and then washed three times in TBS-T. Secondary antibody (peroxidaseconjugated goat anti-rabbit immunoglobulin G (IgG); Jackson ImmunoResearch Laboratories, West Grove, PA, USA) was diluted 1:5000 in blocking solution, and incubated with the blots at room temperature for $1 \mathrm{~h}$. Finally, the blots were washed three to five times in TBS-T. Peroxidase (POD) activity was detected with the ECL Western blotting detection reagent (Amersham), and visualized with Kodak Digital Image Station (NEN Life Science Products, Inc., Belgium).

\section{Immunohistochemistry}

The spleen and thymus were fixed in $4 \%$ PBS-buffered paraformaldehyde $(\mathrm{pH} \quad 7 \cdot 4)$ for 18-24 h, dehydrated in an ascending ethanol series and embedded in paraffin. Sections $(5 \mu \mathrm{m})$ were deparaffinized in xylene and hydrated in a descending ethanol series to distilled water. Antigen retrieval was performed by microwave irradiation in $10 \mathrm{mM}$ citrate buffer $(\mathrm{pH} 6 \cdot 0)$, for $2 \times 8 \mathrm{~min}$ at $750 \mathrm{~W}$, followed by cooling to room temperature and washing twice in distilled water. Endogenous POD activity was blocked in $1 \% \mathrm{H}_{2} \mathrm{O}_{2}$ in PBS for $15 \mathrm{~min}$, followed by washing in PBS for $2 \times 5 \mathrm{~min}$. Blocking solution $(10 \%$ normal rabbit serum in PBS) was applied for $60 \mathrm{~min}$ at room temperature, followed by incubation with the primary antibody, goat anti-IGFBP-4 polyclonal antibody (C-20; Santa Cruz Biotechnology Inc., Heidelberg, Germany), overnight at $4^{\circ} \mathrm{C}$ in a dark humid chamber (the primary antibody was diluted in the blocking solution: for spleen sections, 1:100; for thymus sections, 1:50). Negative controls were incubated with blocking solution without primary antibody. Thereafter, the sections were washed in PBS for $3 \times 5 \mathrm{~min}$. The second antibody, POD-conjugated rabbit anti-goat immunoglobulins (DakoCytomation GmbH, Hamburg, Germany), was diluted 1:100 and applied to each section for $60 \mathrm{~min}$ at room temperature. Sections were washed in PBS for $3 \times 5 \mathrm{~min}$ and developed with $0.05 \%$ 3, $3^{\prime}$-diaminobenzidine (DAB) and $0 \cdot 03 \% \mathrm{H}_{2} \mathrm{O}_{2}$ in PBS for $5 \mathrm{~min}$, followed by counterstaining with hematoxylin.

\section{Determination of body and organ weights}

The body weight of mice was recorded once a week from 1 to 12 weeks of age. Mice from selected groups (at 4, 8 and 12 weeks), were anesthetized with ether, weighed and bled from the retro-orbital sinus. After measurement of the distance between the nose and the base of the tail (nose-rump length, NRL), the mice were killed by cervical dislocation. Organs and carcass were dissected, blotted dry and weighed. Complete organs or parts of them were frozen on dry ice and later stored at $-80{ }^{\circ} \mathrm{C}$ for RNA and protein isolation, or fixed in $4 \%$ paraformaldehyde for histological analysis.

\section{Histomorphometry}

The thymus and spleen were released from the surrounding tissues and weighed to the nearest $0.1 \mathrm{mg}$. Their volumes were determined by the fluid displacement method according to Scherle (1970). The organs were fixed in 4\% paraformaldehyde and embedded in paraffin. Cavalieri's principle (Gundersen \& Jensen 1987) was applied to estimate the volumes of the paraffin-embedded thymus and spleen. First, the embedded organ was trimmed free of paraffin, and its length along the longitudinal axis was recorded. After positioning the first cut randomly within an interval of $1 \mathrm{~mm}$, the organs were exhaustively sectioned perpendicular to their longitudinal axes into parallel slices of approximately $1 \mathrm{~mm}$. These slices were placed with the right-hand cut-surface upward in tissue capsules and re-embedded in paraffin. Sections of $5 \mu \mathrm{m}$ thickness representing systematic samples of the whole organs were prepared and stained with hematoxylin and eosin (HE). Light-microscopic planimetric evaluation was performed on a semiautomated image analysis system (Videoplan; Zeiss-Kontron, Eching, Germany) coupled to a microscope via a color video camera (Panasonic, Japan). A $2.5 \times$ objective was used, providing a $90 \times$ final linear magnification. An object micrometer (Zeiss) was used for calibration. The cross-sectional areas of organ structures of interest were determined on images displayed on a color monitor. These structures included the thymus and its cortex and medulla; and the spleen and its red pulp and white pulp, including the marginal zone. A correction factor for shrinkage due to histological processing was calculated for each organ as the 
volume of the unfixed organ divided by the volume of the embedded organ. Assuming the same extent of shrinkage for the whole organ and its different compartments, the volumes of the different parts of the whole organ were calculated taking the individual shrinkage into account.

\section{Flow cytometry}

Blood (400-600 $\mu \mathrm{l})$ was collected by bleeding from the retro-orbital sinus in a $1 \mathrm{ml}$ lithium-heparin tube (Kabe Labortechnik GmbH, NuembrechtElsenroth, Germany), centrifuged at $4500 \boldsymbol{g}$ for $5 \mathrm{~min}$, and the plasma was recovered for ELISA analysis. The nucleated cells were prepared as described previously (Flaswinkel et al. 2000). Thymus, spleen and subiliac lymph nodes were cut into small pieces in FACS buffer (PBS containing $2 \%$ FCS and $\left.0.01 \% \quad \mathrm{NaN}_{3}\right)$ and were pushed through a $100 \mu \mathrm{m}$ nylon cell strainer (Becton Dickinson Labware, Le Pont de Claix, France) to obtain single-cell suspensions. Subsequently, thymocytes and cells from the lymph node were washed twice in FACS buffer. Erythrocytes in the single-cell suspensions from spleen were removed by incubating in $10 \mathrm{ml}$ lysis buffer $(140 \mathrm{mM}$ $\mathrm{NH}_{4} \mathrm{Cl}, 17 \mathrm{mM}$ Tris-HCl $(\mathrm{pH} 7 \cdot 2)$ ) for $15 \mathrm{~min}$, followed by two washing steps in FACS buffer. Suspensions of bone marrow cells were flushed from the tibia with FACS buffer. Immunofluorescence staining and subsequent measurement as well as data analysis were performed as described previously (Flaswinkel et al. 2000).

\section{In vitro proliferation assay}

Splenocytes were cultured in flat-bottomed, 96-well polystyrene microtiter plates (Nunc, Kamstrup, Denmark) at a density of $2 \times 10^{5}$ cells $/ \mathrm{ml}$ in $200 \mu \mathrm{l}$ RPMI 1640 medium (Gibco) supplemented with $50 \mu \mathrm{M}$ 2-mercaptoethanol (Sigma), $4 \mathrm{mM}$ glutamine, $1 \mathrm{mM}$ pyruvate, $10 \%$ heat-inactivated FCS, $100 \mathrm{U} / \mathrm{ml}$ penicillin and $100 \mu \mathrm{g} / \mathrm{ml}$ streptomycin (Gibco). Splenocytes were stimulated either with $2 \mu \mathrm{g} / \mathrm{ml}$ concanavalin A (Con A; Sigma) or $10 \mu \mathrm{g} / \mathrm{ml}$ lipopolysaccharide (LPS; Sigma). After $48 \mathrm{~h}$ of culture at $37^{\circ} \mathrm{C}$ in an atmosphere of $5 \%$ $\mathrm{CO}_{2}$ and $100 \%$ relative humidity, the cells were pulsed with $1 \mu \mathrm{Ci}\left[{ }^{3} \mathrm{H}\right]$ thymidine (Amersham) per well for an additional $18 \mathrm{~h}$ of culture. The cells were harvested using a Micro 96 harvester (Skatron Instruments, Tranby, Norway). Incorporation of $\left[{ }^{3} \mathrm{H}\right]$ thymidine was quantified in a Betaplate liquid scintillation counter (Wallac, Gaithersburg, MD, USA).

\section{In situ proliferation assay}

Two transgenic and two wild-type mice were injected intraperitoneally with 5bromodeoxyuridine (BrdU; $30 \mu \mathrm{g} / \mathrm{g}$ body weight). The animals were killed $2 \mathrm{~h}$ later. Spleen and thymus were fixed in $70 \%$ ethanol and embedded in paraffin. Sections $(5 \mu \mathrm{m})$ were prepared by standard procedures. Endogenous POD activity was blocked as described above, followed by washing in PBS. Then the sections were incubated in the following solutions separately: $30 \mathrm{~min}$ in $2 \mathrm{M}$ $\mathrm{HCl}$, $1 \mathrm{~min}$ in PBS, $2 \times 10 \mathrm{~min}$ in $70 \%$ ethanol/ $0.1 \mathrm{M}$ Tris $-\mathrm{HCl}(\mathrm{pH} 7 \cdot 5), 2 \times 5 \mathrm{~min}$ in $70 \%$ ethanol, shortly in distilled water and $2 \times 10 \mathrm{~min}$ in PBS. POD-conjugated anti-BrdU antibody (1:10; Roche) was added to the sections and incubated overnight at $4{ }^{\circ} \mathrm{C}$ in a dark humid chamber. Sections were washed in PBS, developed with DAB, counterstained with hematoxylin, and scored under a light microscope (Zeiss Axiovert 200) coupled to a color video camera (Zeiss Axiocam). Photomicrographs were taken and edited using Zeiss Axioversion Image software. The proliferation index (PI) was calculated from the percentage of BrdU-positive cells counted in the red pulp and white pulp of spleen, and in the cortex and medulla of thymus. Five random fields $(50 \mu \mathrm{m} \times 50 \mu \mathrm{m}$, about 100 cells) in the red pulp and white pulp, and cortex and medulla were counted.

\section{In situ apoptosis assay}

The spleen and thymus from two transgenic and two wild-type mice were fixed in $4 \%$ paraformaldehyde, routinely processed and embedded in paraffin. Sections of $5 \mu \mathrm{m}$ thickness were prepared, deparaffinized by standard procedures, treated with $750 \mathrm{~W}$ microwave irradiation for $1 \mathrm{~min}$ in $0 \cdot 1 \mathrm{M}$ citrate buffer $(\mathrm{pH} 6 \cdot 0)$, cooled to room temperature and rinsed in PBS. Endogenous POD activity was blocked as described above, followed by washing in PBS. The terminal deoxynucleotide transferase 


\section{7 bp}

(A)

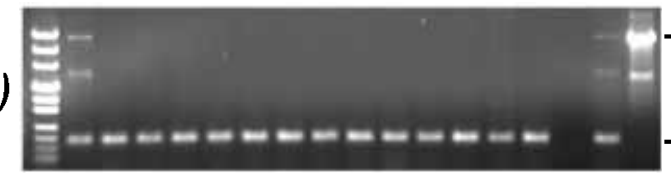

1000

(B)

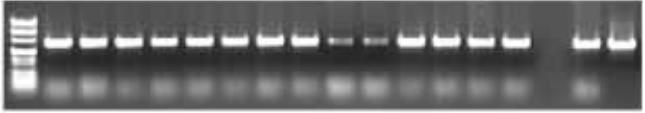

150

(C)

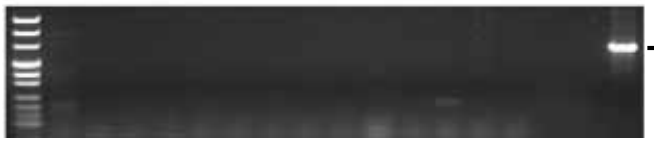

Figure 2 RT-PCR analysis of transgene mRNA expression in different tissues of transgenic mice: adrenal gland (1), bladder (2), brain (3), heart (4), kidney (5), liver (6), lung (7), skeletal muscle (8), ovary (9), salivary gland (10), skin (11), spleen (12), testis (13) and thymus (14). 15, water; 16, IGFBP-4-transfected cells. 17, plasmids $\mathrm{pH}-2 \mathrm{~K}^{\mathrm{b}}$-mIGFBP-4 $(A)$ or pCR-TOP- $\beta$-actin ( $B$ and $C$ ). ( $A$ ) RT-PCR using primers mBP4\#14 and $\beta$-globin\#1. (B) $\beta$-actin RT-PCR. (C) control PCR omitting RT using $\beta$-actin primers.

(TdT)-mediated dUTP nick end labeling (TUNEL) was carried out using the In Situ Cell Death detection kit (Roche). Each experiment was performed with a negative control (labeling solution without TdT). Fluorescein-labeled dNTPs were then detected by incubating sections with converter-POD (POD-conjugated anti-fluorescein antibody; Roche) at $37^{\circ} \mathrm{C}$ for $30 \mathrm{~min}$ in a dark humid chamber. Sections were washed in PBS, developed with $\mathrm{DAB}$ and counterstained with hematoxylin. The apoptosis index (AI) was calculated from the percentage of TUNEL-positive cells counted in the red pulp and white pulp of spleen, and in the cortex and medulla of thymus as described above.

\section{Basal immunoglobulin ELISA}

Basal immunoglobulin levels in plasma were determined by using sandwich ELISAs specific for IgM, IgG3 and IgA as described previously (Flaswinkel et al. 2000).

\section{Autoreactive antibody assay}

Plasma anti-DNA autoreactive antibody levels were determined using the ELISA-based assay as described previously (Flaswinkel et al. 2000).
(A)

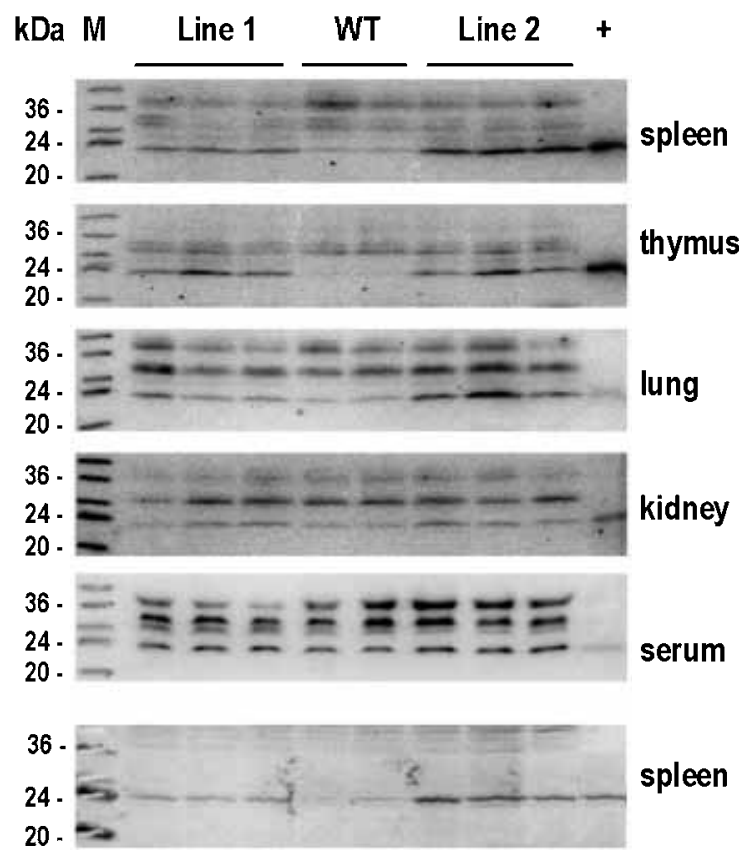

Figure $3^{125}$ I-labeled IGF-II ligand blot $(A)$ and Western immunoblot $(B)$ analysis of IGFBP-4 expression in transgenic and control (WT) mice. IGFBP-4 levels were increased in the spleen, thymus, lung and kidney. No significant change was found in serum for each IGFBP. The serum-free conditioned media from mIGFBP-4-transfected cells were loaded as IGFBP-4 protein-positive control (+).

\section{Statistical analysis}

The data were analyzed for significance of differences using Student's $t$-test. A difference was considered to be statistically significant at $P<0 \cdot 05$.

\section{Results}

\section{Generation of IGFBP-4 transgenic mice and examination of transgene expression}

When conditioned media of NIH-3T3 cells transiently transfected with $\mathrm{pH}-2 \mathrm{~K}^{\mathrm{b}}-\mathrm{mIGFBP}-4$ and mock vector were analyzed by ${ }^{125}$ I-labeled IGF-II ligand blot, the level of a $24 \mathrm{kDa}$ protein was significantly increased in the media from $\mathrm{pH}-2 \mathrm{~K}^{\mathrm{b}}$-mIGFBP-4 transfected cells, compared with the media from the parental cells and mock transfected cells (data not shown). This protein was identified as being IGFBP-4 by Western blot using IGFBP-4 antibodies. 


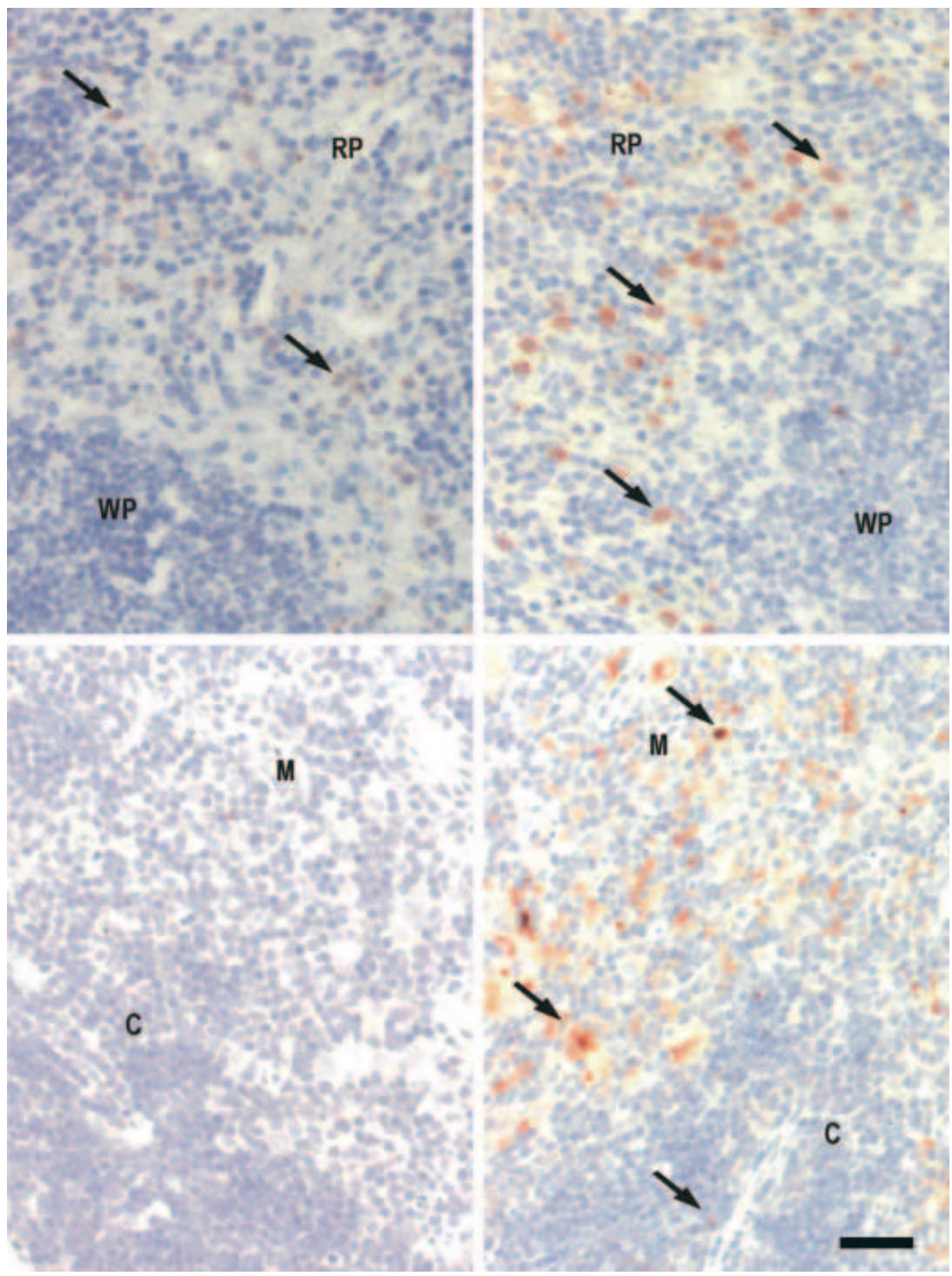

Figure 4 IGFBP-4 immunostaining of the spleen (upper panels) and thymus (lower panels) of wild-type (left) and transgenic mice (right). Strong signals were detected in the red pulp of the spleen (RP) and medulla of the thymus (M) of transgenic mice. WP, white pulp; C, cortex. Scale bar, $20 \mu \mathrm{m}$.

Two founder mice were obtained from the microinjection experiments and were mated with wild-type C57BL/6 mice, generating two transgenic lines. There were more transgene copies integrated in the genome of line 2 than line 1 , as estimated by Southern blot analysis (Fig. 1). The endogenous Igfbp 4 signals were detected at $8 \mathrm{~kb}$ and $2 \cdot 7 \mathrm{~kb}$ in all wild-type and transgenic animals. The $5 \mathrm{~kb}$ microinjection fragment was recovered in both transgenic lines, and the line-specific signal was found at $10 \mathrm{~kb}$ in line 2 and $>10 \mathrm{~kb}$ in line 1 , indicating different integration sites in the two transgenic lines.

RT-PGR revealed ubiquitous expression of the transgene in all organs/tissues tested, including adrenal gland, bladder, brain, heart, kidney, liver, lung, ovary/testis, salivary gland, skeletal muscle, skin, spleen, stomach, small and large intestine, and thymus (Fig. 2). However, elevated IGF-binding activity was only detected in the spleen, thymus, 
Thymus
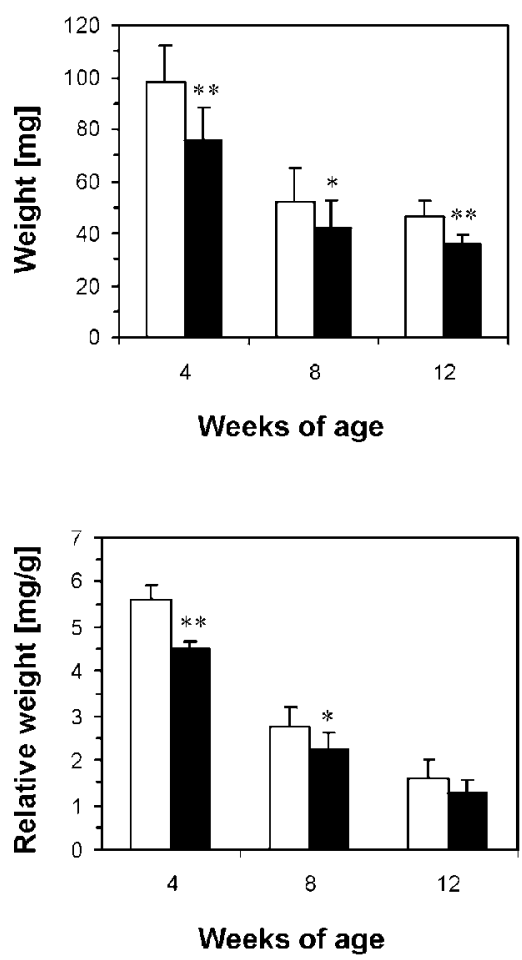

WT
Spleen
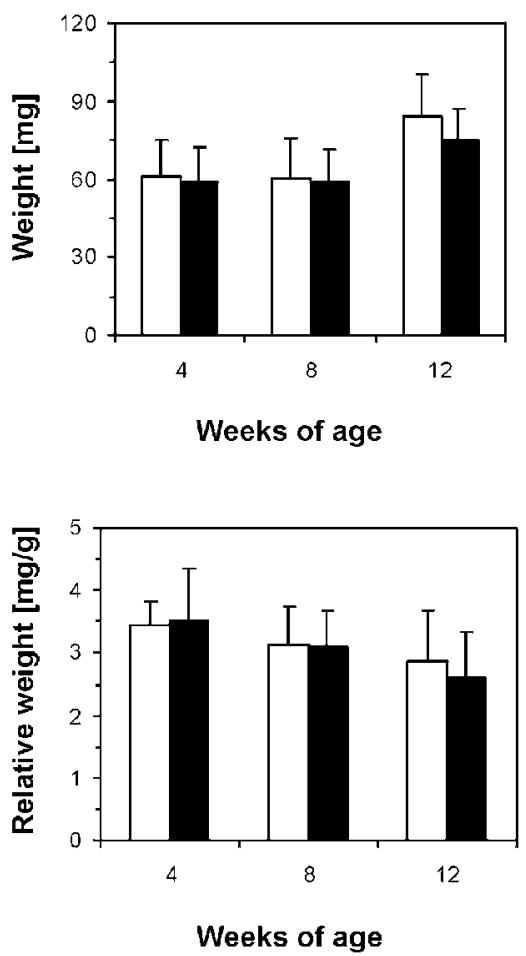

TG

Figure 5 Absolute and relative (relative to body weight) weights of thymus (left) and spleen (right) in transgenic mice (TG) and their wild-type littermates (WT). From each group, 15-20 mice were investigated. Data are presented as means \pm S.D. ${ }^{*} P<0.05,{ }^{*} P<0.01$.

lung and kidney as shown by IGF-II ligand blot (Fig. 3A). The increased IGFBP at $24 \mathrm{kDa}$ in the spleen of transgenic mice was confirmed to be IGFBP-4 by Western blot using IGFBP-4-specific antibodies (Fig. 3B). IGFBP-4 expression was consistently higher in line 2 than in line 1 . The activities of serum IGFBPs were not changed in transgenic mice as shown by Western ligand blot (Fig. 3A).

In order to localize IGFBP-4 expression in the spleen and thymus, immunohistochemical staining was performed. Strong IGFBP-4 immunoreactivity was detected selectively in the splenic red pulp and thymic medulla of transgenic mice. The predominant IGFBP-4 positive cells were macrophages in the red pulp of the spleen and epithelial cells in the thymus medulla (Fig. 4).

\section{Reduced thymus size in IGFBP-4 transgenic mice}

Transgenic mice and non-transgenic littermates from both lines were weighed once a week from 1 to 12 weeks of age to detect the possible effect of transgene expression on body weight gain. No significant difference was observed between transgenic and control animals from both lines (data not shown).

NRL, body and organ weights were recorded in 4-, 8- and 12-week-old animals. There were also no significant differences in NRL, body and organ weights between both groups, with the exception of thymus weight, which was significantly reduced in transgenic mice when compared with controls. This reduction persisted when thymus weight was 

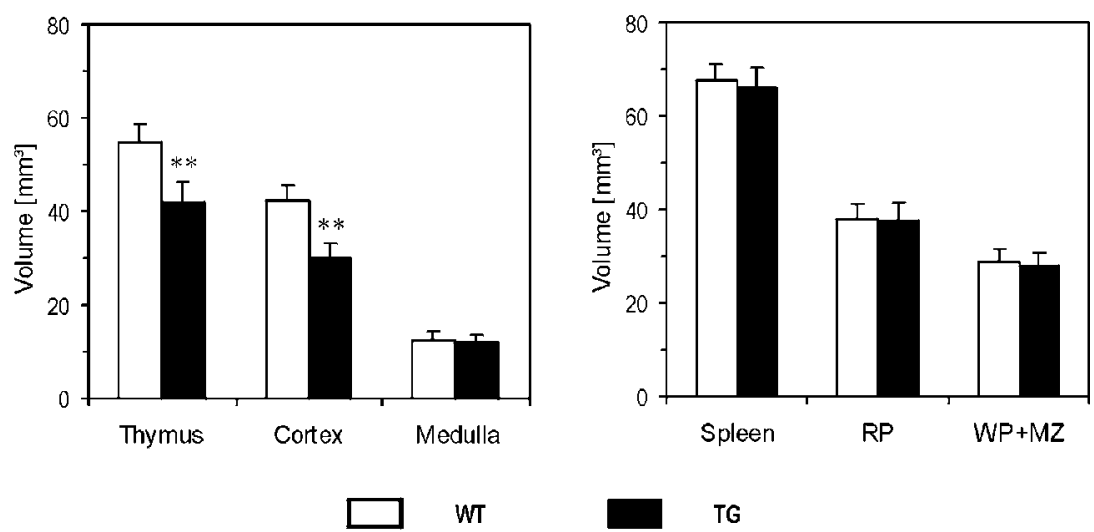

Figure 6 Morphometric determination of the volumes of thymus, spleen and their compartments of 8-week-old transgenic (TG) and control (WT) mice.

Four animals from each group were investigated as described in the Materials and methods section. Data are presented as means \pm S.D ${ }^{* *} P<0.01$.

related to body weight (Fig. 5). Morphometric analysis revealed that the volumes of thymus and its cortex were significantly reduced in transgenic animals compared with control littermates, whereas the volume of thymic medulla was not different between the two groups (Fig. 6). In contrast, there were no significant differences in weight (Fig. 5), total and compartmental volumes of spleen between the two groups (Fig. 6).

\section{Decreased cell proliferation and increased apoptosis in the spleen and thymus of transgenic mice}

To analyze the proliferative capacity of $\mathrm{T}$ - and $\mathrm{B}$-cells of the transgenic mice, splenocytes were stimulated in vitro with mitogens Con A and LPS respectively. $\left[{ }^{3} \mathrm{H}\right]$ thymidine incorporation experiments revealed that the proliferative activity of the transgenic splenocytes was significantly reduced after Con A $(P<0.05)$ and LPS $(P<0.01)$ stimulation (Fig. 7).

To visualize the proliferative status in the spleen and thymus, mice were injected $2 \mathrm{~h}$ before death with BrdU solution. As shown in Fig. 8, BrdU localized to the nuclei of proliferating cells, which were located predominantly in the cortex of thymus and in the red pulp of spleen (Fig. 8). The PI of the red pulp in the transgenic spleen was significantly decreased to $4 \cdot 7 \pm 3 \cdot 0 \%$ compared with $8 \cdot 6 \pm$ $1 \cdot 2 \%$ in control animals $(P<0.05)$, and that of thymic cortex was decreased to $3.9 \pm 2.8 \%$ compared with $12 \cdot 9 \pm 2 \cdot 7 \%$ in the controls
$(P<0 \cdot 001)$, while the PIs of splenic white pulp and thymic medulla were not different between transgenic and control mice.

We then performed TUNEL analysis of tissue sections of spleen and thymus to detect cells carrying fragmented DNA characteristic for apoptotic cells. TUNEL-positive cells located predominantly in the splenic red pulp and thymic cortex (Fig. 9). The AI of the red pulp in transgenic mice was significantly increased to $6 \cdot 4 \pm 3 \cdot 2 \%$ compared with $2 \cdot 2 \pm 1 \cdot 1 \%$ in control animals $(P<0 \cdot 05)$, and that of thymic cortex was increased to $20 \cdot 2 \pm 6 \cdot 4 \%$ compared with $12.9 \pm 2.7 \%$ in the controls $(P<0 \cdot 01)$, while the AIs of splenic white pulp and thymic medulla were not significantly different between the two groups.

\section{Normal lymphocyte development}

To investigate the potential effect of transgene expression in the thymus and spleen on the lymphocyte development, the lymphocytes from the thymus, bone marrow, spleen, lymph node and peripheral blood of transgenic and control mice were analyzed by flow cytometry, using antibodies against different markers expressed on $\mathrm{T}$ - and B-cells and other populations of lymphocytes. FACS analysis did not reveal any significant differences in percentages of different cell populations from the primary and secondary immune organs (Fig. 10) as well as in peripheral blood (data not shown). 


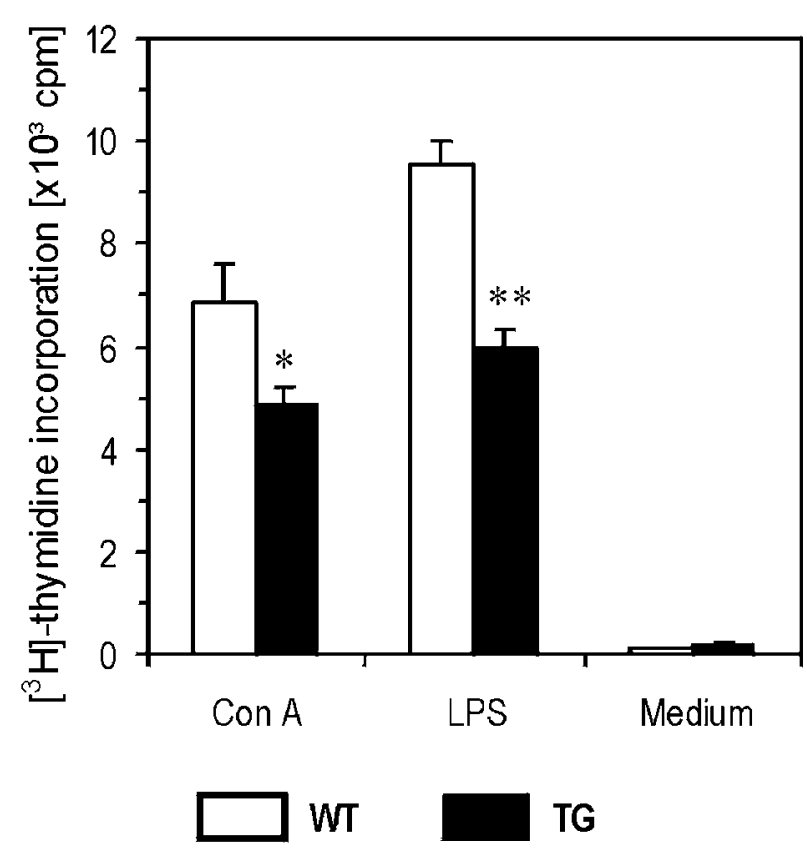

Figure 7 In vitro proliferation assay. Splenocytes from 4-week-old transgenic (TG) mice $(n=3)$ and their wild-type (WT) littermates $(n=3)$ were cultured in 96-well microtiter plates at a density of $2 \times 10^{5}$ cells $/ \mathrm{ml}$ and were stimulated with Con A or LPS. Incorporation of $\left[{ }^{3} \mathrm{H}\right]$ thymidine was quantified as described in the Materials and methods section. Data are presented as means \pm S.D. ${ }^{\star} P<0.05,{ }^{\star \star} P<0.01$.

\section{Normal plasma immunoglobulin and autoreactive antibody levels}

To detect possible effects of transgene expression on the production of the basal immunoglobulins and autoreactive antibodies, the plasma levels of IgM, IgG3, IgA and anti-DNA autoreactive antibodies were determined. Their levels in transgenic mice were not different from those of wild-type littermates (Fig. 11).

\section{Discussion}

The cross-talk between the endocrine and immune systems has been suggested by numerous studies (for reviews see: Blalock 1994, Madden \& Felten 1995, Besedovsky \& del Rey 1996). Cytokines, the soluble factors secreted by the immune cells, exert biological actions on the endocrine system (Silva et al. 1998), conversely, a variety of hormones and peptide growth factors have receptors in the tissues of the immune system and modulate immune functions (Dorshkind \& Horseman 2000). IGF-I and IGF-II are not only involved in endocrine modulation of the development and function of the immune system, but also act as cytokines to regulate local growth and differentiation (Buul-Offers \& Kooijman 1998, Jeay et al. 2002). As important regulators, IGFBPs may also be involved in these processes. To investigate IGFBP-4 actions, we generated transgenic mice overexpressing IGFBP-4. As the transgene was highly expressed in the spleen and thymus, we had the opportunity to characterize the effects of IGFBP-4 excess on growth and development of these organs.

\section{Transgene expression}

Transgenic mRNA was expressed ubiquitously in all tissues of transgenic mice (Fig. 2), and elevated protein levels were detected in the spleen, thymus, lung and kidney (Fig. 3). Immunohistochemical studies revealed that strong IGFBP-4 immunoreactivity was located selectively in the red pulp of the spleen and the medulla of the thymus. The majority of IGFBP-4-positive cells were macrophages in the spleen red pulp and epithelial cells in the thymus medulla (Fig. 4). This result is in agreement with the location of IGF-II expression in the H-2 $\mathrm{K}^{\mathrm{b}}$-hIGF-II transgenic mice (Van der Ven et al. 1997). The expression pattern of the transgene was identical in the two different transgenic lines, indicating that expression of the transgene occurs independently of the integration sites. Elevated IGFBP-4 protein levels were detected in the spleen, thymus, lung and kidney, corresponding to high expression of the $\mathrm{H}-2 \mathrm{~K}^{\mathrm{b}}$ gene in these organs (Morello et al. 1986). The murine $\mathrm{H}-2 \mathrm{~K}^{\mathrm{b}}$ promoter has been used by several investigators for generations of transgenic mice expressing human growth hormone (hGH) (Morello et al. 1986), c-myc (Morello et al. 1989), c-fos (Ruther et al. 1988), hIGF-II (Buul-Offers et al. 1995) and mutant forms of the tumor necrosis factor receptor p55 (TNFRp55) (Plitz et al. 1999). In these mice, a tissue specificity similar to the endogenous $H-2 K^{b}$ mRNA expression was also observed.

\section{Effects on body and organ growth}

To investigate potential effects of transgene expression on body and organ growth, a large 

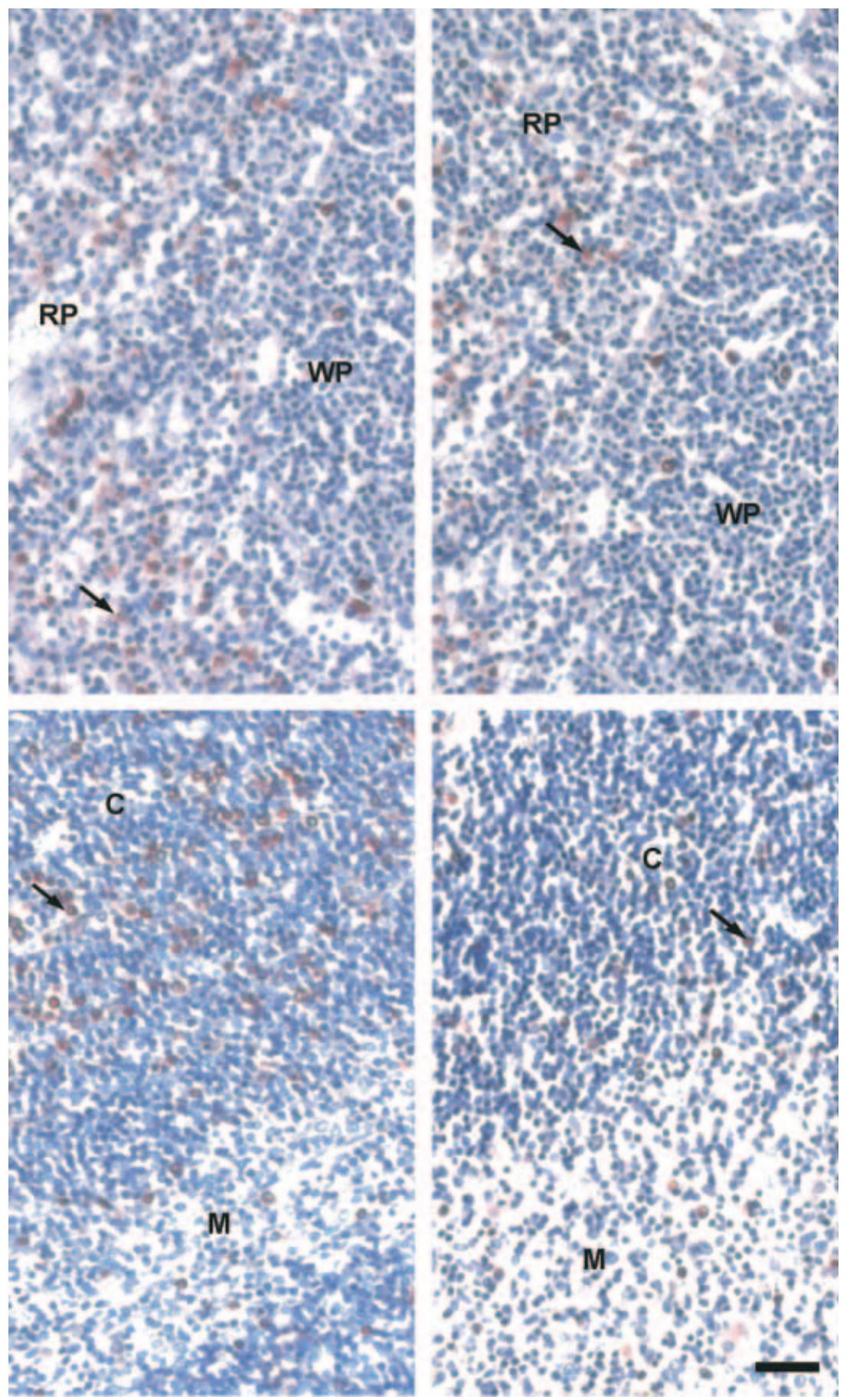

Figure $8 \mathrm{BrdU}$ staining of the spleen (upper panels) and thymus (lower panels). Cell proliferation is documented by the presence of BrdU-positive cells (arrows), which are located predominantly in the red pulp (RP) and cortex $(C)$. Note the decrease of proliferation rate in transgenic mice (right) compared with control mice (left). Scale bar, $20 \mu \mathrm{m}$. 

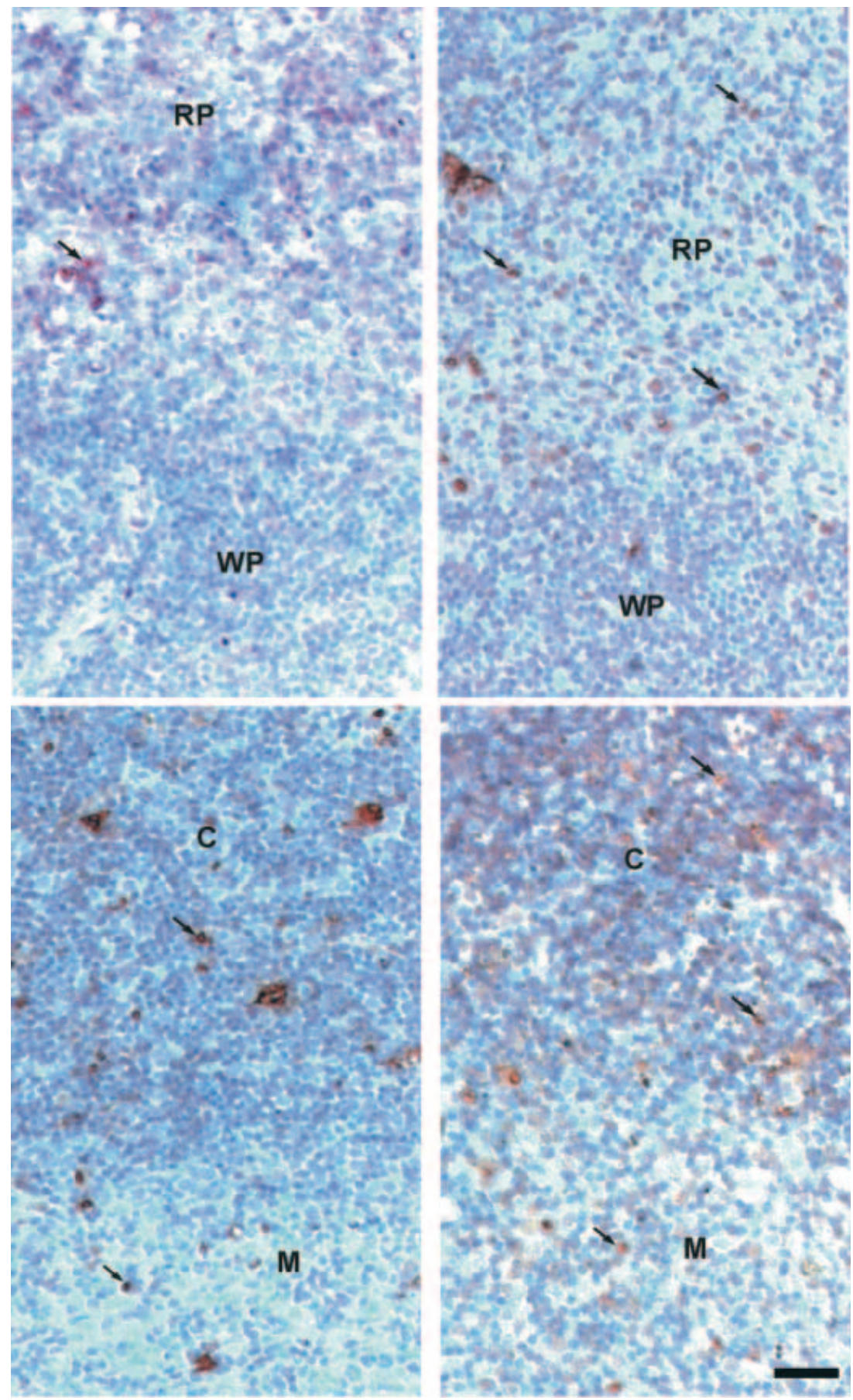

Figure 9 TUNEL staining of the spleen (upper panels) and thymus (lower panels). Apoptotic cells (arrows) are located in the red pulp (RP) and cortex (C). Note the increase of apoptosis rate in transgenic mice (right) compared with wild-type mice (left). Scale bar, $20 \mu \mathrm{m}$. 

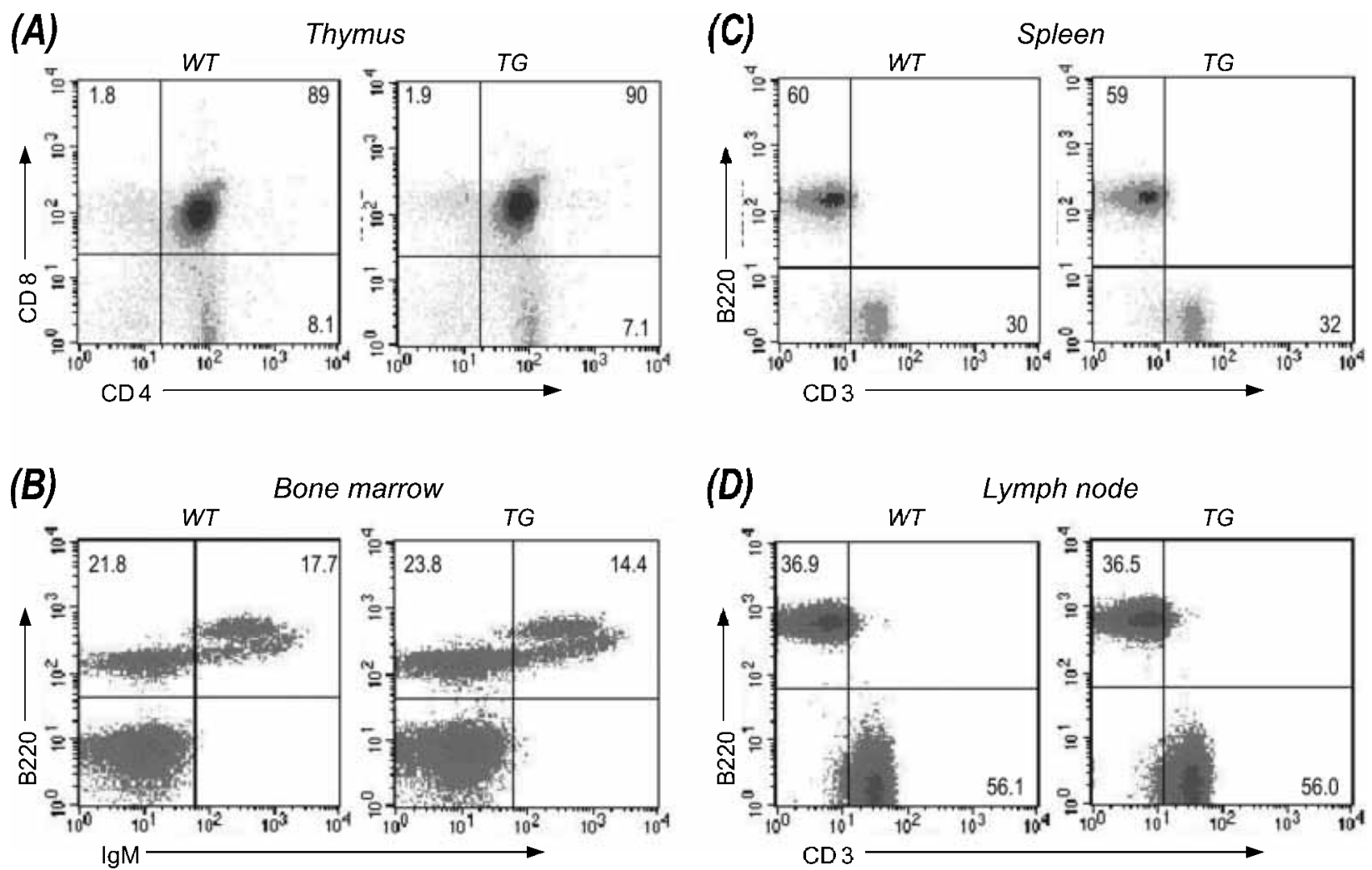

Figure 10 Flow cytometric analysis of T- and B-cell development of 4-week-old transgenic (TG) and control (WT) mice. Three animals from each group were analysed. Density plots with characteristic stainings are shown. $(A)$ Thymocyte development in the thymus from CD4/CD8 double-negative to CD4/CD8 double-positive and then to the CD4 or CD8 single-positive stages is not significantly different between TG and WT mice. (B) Development of B-cells in the bone marrow. Cells are gated on $\mathrm{CD}^{4} 3^{-}$. Development proceeds comparably from pre-B cells $\left(\operatorname{lgM}^{-} / \mathrm{B}^{2} 20^{+}\right)$to immature B-cells $\left(\mathrm{IgM}^{+} / \mathrm{B}_{2} 2 \mathrm{O}^{+}\right)$and finally to mature B-cells $\left(\mathrm{IgM}^{+} / \mathrm{B} 220 \mathrm{high}\right)$ in $\mathrm{TG}$ and WT mice. Secondary lymphoid organs are represented by spleen $(C)$ and lymph node $(D)$. In both cases expression of typical markers and distribution of T- and B-cells is not different between TG and WT mice.

panel of allometric measurements was carried out as described in the Materials and methods section.

The marked decrease in weight and volume of the thymus in the postnatal life is the outstanding feature of the $\mathrm{H}-2 \mathrm{~K}^{\mathrm{b}}$-IGFBP-4 transgenic mice (Fig. 5). Although the transgene was also expressed in the spleen, kidney and lung, the weights of these organs were not changed (data for kidney and lung were not shown), suggesting that IGFBP-4 overexpression does not affect postnatal growth of these organs. However, ultrastructural studies need to be done to clarify this point further.

In order to define the histological alterations in the thymus and spleen, histomorphometric analyses were performed. The transgenic mice showed a significant decrease in thymic cortex volume compared with the controls, whereas the volume of the medulla was not altered (Fig. 6). IGFBP-4 was selectively expressed in the medulla of the thymus, but the histological effect was confined to the cortex. This finding is in agreement with the IGF-II effect in $\mathrm{H}-2 \mathrm{~K}^{\mathrm{b}}$-hIGF-II transgenic mice (Van der Ven et al. 1997), and may be due to a paracrine effect of IGFBP-4 and a relatively higher sensitivity of the cortical compartment to IGFBP-4. These notions were supported by the in situ proliferation and apoptosis studies, which revealed that proliferating and apoptotic cells were predominantly located in the cortex, and that cell proliferation was inhibited and apoptosis was stimulated selectively in the cortex of transgenic mice but not in the medulla (Figs 8 and 9). Although IGFBP-4 was also expressed in the spleen of transgenic mice, no alteration in the architecture of the spleen was 


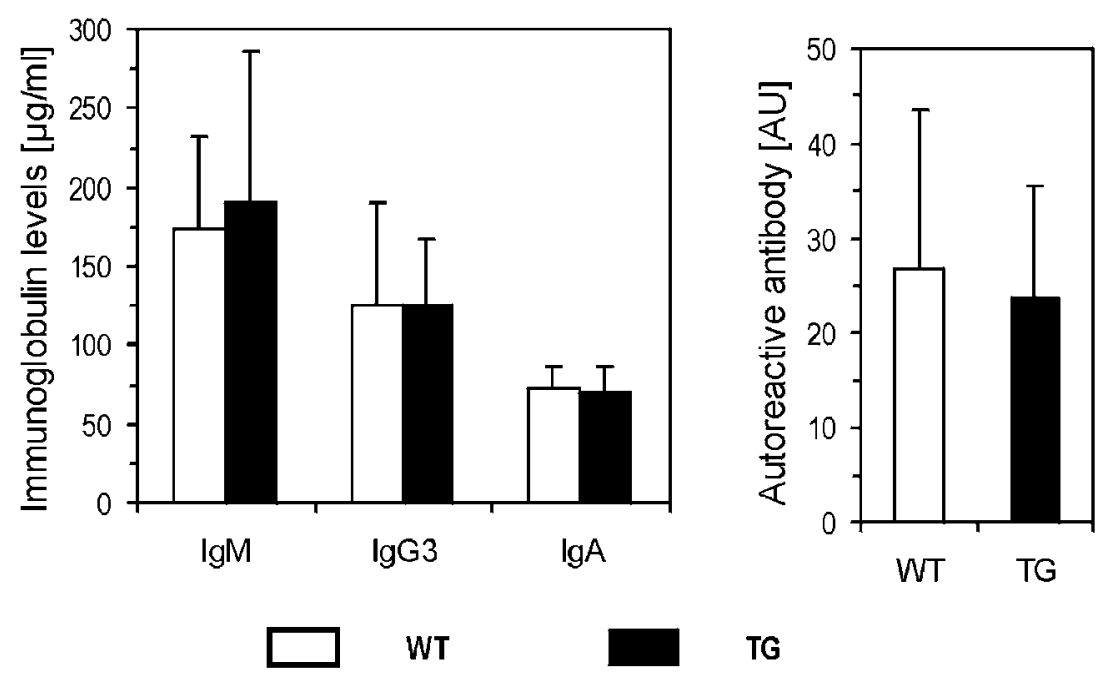

Figure 11 Determination of the levels of plasma basal immunoglobulins and anti-DNA autoreactive antibodies. Ten animals from each group were investigated. No significant differences were detected between the two groups.

observed; this is in agreement with the unchanged weight and volume of this organ. Interestingly, $\mathrm{H}-2 \mathrm{~K}^{\mathrm{b}}$-hIGF-II transgenic mice did not show a spleen phenotype either (Buul-Offers et al. 1995, Van der Ven et al. 1997). hIGF-II was highly expressed in the spleen, thymus and liver of these mice, but only the postnatal growth of the thymus was promoted by IGF-II overexpression. The absence of splenomegaly in $\mathrm{H}-2 \mathrm{~K}^{\mathrm{b}}$-hIGF-II transgenic mice was suggested to be a consequence of upregulation of IGFBP-3 expression in the spleen by elevated IGF-II (Smink et al. 1999). Whether the expression of some growth-regulating genes was altereded by IGFBP-4 overexpression in the spleen, lung and kidney of our transgenic mice is unknown. The exclusive effect of IGFBP-4 on the growth of the thymus might be the consequence of an interaction with a thymus-specific factor whose identity, however, remains to be unravelled.

\section{Effects on the immune functions}

The functions of the IGF components in the immune system are very complex. Systemic administration of IGF-I significantly increased the size and cellularity of both primary and secondary lymphoid organs in rodents (Binz et al. 1990, Beschorner et al. 1991, Murphy et al. 1992, Clark et al. 1993, Jardieu et al. 1994). Furthermore, IGF-I administration enhanced immune response and altered lymphocyte survival and regeneration in thymus and spleen of dexamethasone-treated rats (Hinton et al. 1995, 1998). Administration of IGF-II also stimulates growth of the thymus and spleen, but to a lesser extent than IGF-I (Buul-Offers et al. 1994, Conlon et al. 1995). Overexpression of IGF-I in mice stimulates $\mathrm{T}$ - and B-cell development and antigen-specific IgG synthesis (Clark et al. 1993, Robbins et al. 1994). Overexpression of IGF-II in transgenic mice stimulated the development of phenotypically normal T-cells but not mature B-cells (Kooijman et al. 1995, 1997). IGFBPs are also expressed by lymphoid tissues. Normal human peripheral lymphocytes were shown to express mRNA for IGFBP-2 and -3, and after mitogenic stimulation they additionally express IGFBP-4 and -5 (Grellier et al. 1995). Thymic epithelial cells express different levels of IGFBP-2 to -6, with a predominance of IGFBP-4 (Kecha et al. 1999). IGFBP-4 has also been detected in murine thymic macrophages and in macrophage cell lines ( $\mathrm{Li}$ et al. 1996). Overexpression of IGFBP-1 in transgenic mice led to inconsistent effects on spleen size (Dai et al. 1994, Murphy et al. 1995a, Rajkumar et al. 1995), overexpression of IGFBP-2 reduced spleen weight of male transgenic mice (Hoeflich et al. 1999), whereas overexpression of IGFBP-3 increased spleen size (Murphy et al. 1995b). 
IGFBP-2 knockout mice show no gross phenotype except for a reduced spleen size (Wood et al. 2000).

Considering the high transgene expression in the spleen and thymus, we focused on the investigation of potential effects of IGFBP-4 overexpression on immune functions. First, the mitogenic response of $\mathrm{T}$ - and B-cells was determined by in vitro proliferation assays using $\mathrm{T}$ - and B-cell mitogens. The proliferative activity of the splenocytes was significantly reduced in transgenic mice after Con A and LPS stimulation (Fig. 7). To address the lymphocyte development of IGFBP-4 transgenic mice, FACS analysis was performed. No changes were found in percentages of different cell populations from the primary and secondary immune organs of transgenic mice (Fig. 10). This finding suggests that IGFBP-4 excess in the thymus and spleen did not affect the development of the immune-related cells. Finally, plasma levels of basal immunoglobulins and anti-DNA autoreactive antibodies were determined. No significant differences were found between transgenic and control animals (Fig. 11). These results indicate that IGFBP-4 excess in the thymus and spleen has no effect on the production of the humoral immunocompetence, and does not induce autoimmune disorders in transgenic mice.

In conclusion, overexpression of IGFBP-4 inhibits the growth of the thymus. IGFBP-4 excess inhibits cell proliferation and stimulates cell apoptosis in the lymphoid tissues, but does not affect lymphocytic development. These findings suggest that IGFBP-4 is a potential growth inhibitor of the lymphoid tissues.

\section{Funding}

RZ and MRS were supported by the German Academic Exchange Service (DAAD).

\section{References}

Beschorner WE, Divic J, Pulido H, Yao X, Kenworthy P \& Bruce G 1991 Enhancement of thymic recovery after cyclosporine by recombinant human growth hormone and insulin-like growth factor I. Transplantation 52 879-884.

Besedovsky HO \& del Rey A 1996 Immune-neuro-endocrine interactions: facts and hypotheses. Endocrine Reviews 17 64-102.

Binz K, Joller P, Froesch P, Binz H, Zapf J \& Froesch ER 1990 Repopulation of the atrophied thymus in diabetic rats by insulin-like growth factor I. PNAS 87 3690-3694.

Blalock JE 1994 The syntax of immune-neuroendocrine communication. Immunology Today 15 504-511.
Buul-Offers SC \& Kooijman R 1998 The role of growth hormone and insulin-like growth factors in the immune system. Cellular and Molecular Life Sciences 54 1083-1094.

Buul-Offers SC, Reijnen-Gresnigt MG, Hoogerbrugge CM, Bloemen RJ, Kuper CF \& van den Brande JL 1994 Recombinant insulin-like growth factor-II inhibits the growth-stimulating effect of growth hormone on the liver of Snell dwarf mice. Endocrinology 135 977-985.

Buul-Offers SC, de Haan K, Reijnen-Gresnigt MG, Meinsma D, Jansen M, Oei SL, Bonte EJ, Sussenbach JS \& van den Brande JL 1995 Overexpression of human insulin-like growth factor-II in transgenic mice causes increased growth of the thymus. Fournal of Endocrinology 144 491-502.

Clark R, Strasser J, McCabe S, Robbins K \& Jardieu P 1993 Insulin-like growth factor-1 stimulation of lymphopoiesis. Fournal of Clinical Investigation 92 540-548.

Conlon MA, Francis GL, Tomas FM, Wallace JC, Howarth GS \& Ballard FJ 1995 Continuous 14 day infusion of IGF-II increases the growth of normal female rats, but exhibits a lower potency than IGF-I. Fournal of Endocrinology 144 91-98.

Dai Z, Xing Y, Boney CM, Clemmons DR \& D'Ercole AJ 1994 Human insulin-like growth factor-binding protein-1 (hIGFBP-1) in transgenic mice: characterization and insights into the regulation of IGFBP-1 expression. Endocrinology 135 1316-1327.

Dorshkind K \& Horseman ND 2000 The roles of prolactin, growth hormone, insulin-like growth factor-I, and thyroid hormones in lymphocyte development and function: insights from genetic models of hormone and hormone receptor deficiency. Endocrine Reviews 21 292-312.

Firth SM \& Baxter RC 2002 Cellular actions of the insulin-like growth factor binding proteins. Endocrine Reviews 23 824-854.

Flaswinkel H, Alessandrini F, Rathkolb B, Decker T, Kremmer E, Servatius A, Jakob T, Soewarto D, Marschall S, Fella C et al. 2000 Identification of immunological relevant phenotypes in ENU mutagenized mice. Mammalian Genome 11 526-527.

Grellier P, Yee D, Gonzalez M \& Abboud SL 1995 Characterization of insulin-like growth factor binding proteins (IGFBP) and regulation of IGFBP-4 in bone marrow stromal cells. British fournal of Haematology 90 249-257.

Gundersen HJ \& Jensen EB 1987 The efficiency of systematic sampling in stereology and its prediction. Fournal of Microscopy 147 229-263.

Hinton PS, Peterson CA, Lo HC, Yang H, McCarthy D \& Ney DM 1995 Insulin-like growth factor-I enhances immune response in dexamethasone-treated or surgically stressed rats maintained with total parenteral nutrition. Fournal of Parenteral and Enteral Nutrition $19444-452$.

Hinton PS, Peterson CA, Dahly EM \& Ney DM 1998 IGF-I alters lymphocyte survival and regeneration in thymus and spleen after dexamethasone treatment. American Fournal of Physiology $\mathbf{2 7 4}$ R912-R920.

Hoeflich A, Wu M, Mohan S, Foll J, Wanke R, Froehlich T, Arnold GJ, Lahm H, Kolb HJ \& Wolf E 1999 Overexpression of insulin-like growth factor-binding protein-2 in transgenic mice reduces postnatal body weight gain. Endocrinology 140 5488-5496.

Hwa V, Oh Y \& Rosenfeld RG 1999 The insulin-like growth factor-binding protein (IGFBP) superfamily. Endocrine Reviews 20 761-787.

Jardieu P, Clark R, Mortensen D \& Dorshkind K 1994 In vivo administration of insulin-like growth factor-I stimulates primary B lymphopoiesis and enhances lymphocyte recovery after bone marrow transplantation. Journal of Immunology 152 $4320-4327$.

Jeay S, Sonenshein GE, Postel-Vinay MC, Kelly PA \& Baixeras E 2002 Growth hormone can act as a cytokine controlling survival and proliferation of immune cells: new insights into signaling pathways. Molecular and Cellular Endocrinology 188 1-7. 
Kecha O, Martens H, Franchimont N, Achour I, Hazee-Hagelstein MT, Charlet-Renard C, Geenen V \& Winkler R 1999 Characterization of the insulin-like growth factor axis in the human thymus. Fournal of Neuroendocrinology 11 435-440.

Kooijman R, Buul-Offers SC, Scholtens LE, Schuurman HJ, Van den Brande LJ \& Zegers BJ 1995 T cell development in insulin-like growth factor-II transgenic mice. Fournal of Immunology $1545736-5745$.

Kooijman R, Buul-Offers SC, Scholtens LE, Reijnen-Gresnigt RG \& Zegers BJ $1997 \mathrm{~T}$ and B cell development in pituitary deficient insulin-like growth factor-II transgenic dwarf mice. Fournal of Endocrinology 155 165-170.

Li YM, Arkins S, McCusker RH Jr, Donovan SM, Liu Q, Jayaraman S, Dantzer R \& Kelley KW 1996 Macrophages synthesize and secrete a 25-kilodalton protein that binds insulin-like growth factor-I. Fournal of Immunology 156 64-72.

Madden KS \& Felten DL 1995 Experimental basis for neural-immune interactions. Physiological Reviewes 75 77-106.

Miyakoshi N, Richman C, Qin X, Baylink DJ \& Mohan S 1999 Effects of recombinant insulin-like growth factor-binding protein-4 on bone formation parameters in mice. Endocrinology 140 $5719-5728$.

Miyakoshi N, Qin X, Kasukawa Y, Richman C, Srivastava AK, Baylink DJ \& Mohan S 2001 Systemic administration of insulin-like growth factor (IGF)-binding protein-4 (IGFBP-4) increases bone formation parameters in mice by increasing IGF bioavailability via an IGFBP-4 protease-dependent mechanism. Endocrinology 142 2641-2648.

Mohan S \& Baylink DJ 2002 IGF-binding proteins are multifunctional and act via IGF-dependent and -independent mechanisms. Fournal of Endocrinology 175 19-31.

Mohan S, Bautista CM, Wergedal J \& Baylink DJ 1989 Isolation of an inhibitory insulin-like growth factor (IGF) binding protein from bone cell-conditioned medium: a potential local regulator of IGF action. PNAS 86 8338-8342.

Morello D, Moore G, Salmon AM, Yaniv M \& Babinet C 1986 Studies on the expression of an H-2K/human growth hormone fusion gene in giant transgenic mice. EMBO Fournal 5 1877-1883.

Morello D, Asselin C, Lavenu A, Marcu KB \& Babinet C 1989 Tissue-specific post-transcriptional regulation of c-myc expression in normal and $\mathrm{H}-2 \mathrm{~K} /$ human c-myc transgenic mice. Oncogene $\mathbf{4}$ 955-961.

Murphy WJ, Durum SK \& Longo DL 1992 Role of neuroendocrine hormones in murine $\mathrm{T}$ cell development. Growth hormone exerts thymopoietic effects in vivo. Fournal of Immunology 149 3851-3857.

Murphy LJ, Rajkumar K \& Molnar P 1995a Phenotypic manifestations of insulin-like growth factor binding protein- 1 (IGFBP-1) and IGFBP-3 overexpression in transgenic mice. Progress in Growth Factor Research 6 425-432.

Murphy LJ, Molnar P, Lu X \& Huang H $1995 b$ Expression of human insulin-like growth factor-binding protein-3 in transgenic mice. Fournal of Molecular Endocrinology 15 293-303.

Plitz T, Huffstadt U, Endres R, Schaller E, Mak TW, Wagner H \& Pfeffer K 1999 The resistance against Listeria monocytogenes and the formation of germinal centers depend on a functional death domain of the $55 \mathrm{kDa}$ tumor necrosis factor receptor. European fournal of Immunology 29 581-591.

Rajkumar K, Barron D, Lewitt MS \& Murphy LJ 1995 Growth retardation and hyperglycemia in insulin-like growth factor binding protein-1 transgenic mice. Endocrinology 136 4029-4034.
Robbins K, McCabe S, Scheiner T, Strasser J, Clark R \& Jardieu P 1994 Immunological effects of insulin-like growth factor-I enhancement of immunoglobulin synthesis. Clinical and Experimental Immunology 95 337-342.

Ruther U, Muller W, Sumida T, Tokuhisa T, Rajewsky K \& Wagner EF 1988 c-fos expression interferes with thymus development in transgenic mice. Cell 53 847-856.

Scherle W 1970 A simple method for volumetry of organs in quantitative stereology. Mikroskopie 26 57-60.

Schneider MR, Zhou R, Hoeflich A, Krebs O, Schmidt J, Mohan S, Wolf E \& Lahm H 2001 Insulin-like growth factor-binding protein-5 inhibits growth and induces differentiation of mouse osteosarcoma cells. Biochemical and Biophysical Research Communications $288435-442$.

Silva CM, Isgaard J \& Thorner MO 1998 Cytokines in endocrine function. Advances in Protein Chemistry 52 199-221.

Smink JJ, Koster JG, Hendriks-Stegeman BI \& Buul-Offers SC 1999 Insulin-like growth factor (IGF) II induced changes in expression of IGF binding proteins in lymphoid tissues of hIGF-II transgenic mice. Endocrinology 140 5876-5882.

Stewart CE \& Rotwein P 1996 Growth, differentiation, and survival: multiple physiological functions for insulin-like growth factors. Physiological Reviews 76 1005-1026.

Ui M, Shimonaka M, Shimasaki S \& Ling N 1989 An insulin-like growth factor-binding protein in ovarian follicular fluid blocks follicle-stimulating hormone-stimulated steroid production by ovarian granulosa cells. Endocrinology 125 912-916.

Van der Ven LT, Roholl PJ, Reijnen-Gresnigt MG, Bloemen RJ \& Buul-Offers SC 1997 Expression of insulin-like growth factor II (IGF-II) and histological changes in the thymus and spleen of transgenic mice overexpressing IGF- II. Histochemistry and Cell Biology 107 193-203.

Wang J, Niu W, Nikiforov Y, Naito S, Chernausek S, Witte D, LeRoith D, Strauch A \& Fagin JA 1997 Targeted overexpression of IGF-I evokes distinct patterns of organ remodeling in smooth muscle cell tissue beds of transgenic mice. Fournal of Clinical Investigation 100 1425-1439.

Wang J, Niu W, Witte DP, Chernausek SD, Nikiforov YE, Clemens TL, Sharifi B, Strauch AR \& Fagin JA 1998 Overexpression of insulin-like growth factor-binding protein-4 (IGFBP- 4) in smooth muscle cells of transgenic mice through a smooth muscle alpha-actin-IGFBP-4 fusion gene induces smooth muscle hypoplasia. Endocrinology $1392605-2614$.

Wood TL, Rogler LE, Czick ME, Schuller AG \& Pintar JE 2000 Selective alterations in organ sizes in mice with a targeted disruption of the insulin-like growth factor binding protein-2 gene. Molecular Endocrinology 14 1472-1482.

Zhang M, Smith EP, Kuroda H, Banach W, Chernausek SD \& Fagin JA 2002 Targeted expression of a protease-resistant IGFBP-4 mutant in smooth muscle of transgenic mice results in IGFBP-4 stabilization and smooth muscle hypotrophy. Fournal of Biological Chemistry 277 21285-21290.

Zhou R, Diehl D, Hoeflich A, Lahm H \& Wolf E 2003 IGF-binding protein-4: biochemical characteristics and functional consequences. Fournal of Endocrinology 178 177-193.

\section{Received in final form 2 December 2003 Accepted 23 December 2003}

